\title{
PENGARUH MOTIVASI KERJA TERHADAP KOMITMEN ORGANISASI KARYAWAN MAGANG BAKTI BCA PADA PT. BANK CENTRAL ASIA TBK. KANTOR CABANG UTAMA JAMBI
}

\author{
Sakinah As, Firdaus Warbyal Ilham
}

\begin{abstract}
The research aims to analyze the influence of work motivationon organizational commitment. This research is done on Bakti BCA internship employee who work as teller and customer services of PT. Bank Central Asia Tbk.main branch office of Jambi amounted at 60 people. Technique used in sampling is census, where all of the population is used as sample. Analysis unit used is simple linear regression. The research result that work motivation influence positively and significantly on organizational commitment.
\end{abstract}

Keywords: work motivation, organizational commitment.

\section{PENDAHULUAN}

Manajemen Sumber Daya Manusia adalah bagian dari aktivitas manajemen. Manusia sebagai sebuah sumber daya di dalam organisasi, haruslah diatur sedemikian rupa agar terkoordinasi dengan baik dan bisa mendukung pencapaian rencana strategis organisasi. Setiap organisasi tidak mungkin bisa sukses tanpa keberadaan orang-orang di balik organisasi tersebut. Perusahaan besar seperti PT. Bank Central Asia Tbk. tidak akan mungkin menjadi besar seperti saat ini apabila tidak didukung oleh orang-orang hebat dibaliknya. Sumber daya manusia merupakan salah satu faktor produksi yang sangat penting di dalam menjalankan roda kegiatan dalam suatu perusahaan atau instansi (Zahari, 2015:45). Selain itu sumber daya manusia diharapkan mampu memberikan fungsi yang bermanfaat positif bagi perusahaan, masyarakat dan kepentingan individu.

Pencapaian tujuan perusahaan dan kemampuan bersaing akan tergantung pada baik dan buruknya program pengembangan sumber daya manusia yang dilaksanakan oleh perusahaan. Salah satu upaya yang perlu dilakukan oleh perusahaan adalah meningkatkan kinerja karyawan dengan cara memberikan motivasi. Motivasi merupakan hal yang mendorong, mendukung perilaku seseorang untuk melakukan suatu tindakan karena adanya kemauan dan kesediaan bekerja. Motivasi untuk bekerja ini sangat penting dan berpengaruh pada produktivitas perusahaan. Tanpa adanya motivasi dari karyawan untuk bekerja sama bagi kepentingan perusahaan, maka tujuan yang telah ditetapkan tidak akan tercapai. Sebaliknya, apabila terdapat motivasi kerja yang tinggi, maka akan menjadi jaminan atas keberhasilan perusahaan dalam mencapai tujuannya. (Adisetiawan, 2014)

Upaya pemberian motivasi tersebut merupakan salah satu cara untuk mewujudkan komitmen kerja karyawan pada perusahaan. Komitmen organisasional sering didefinisikan sebagai sebuah keinginan kuat untuk tetap menjadi anggota organisasi tertentu, keinginan untuk mendesak usaha pada tingkat tinggi atas nama organisasi, dan keyakinan yang pasti dalam dan penerimaan atas nilai-nilai dan tujuan organisasi. Dengan kata lain komitmen adalah suatu sikap yang mencerminkan loyalitas pekerja pada organisasi dan merupakan suatu proses yang sedang berjalan melalui mana peserta organisasi meyatakan perhatian mereka terhadap organisasi dan kelanjutan keberhasilan dan kesejahteraannya. Obyek penelitian ini adalah karyawan magang Bakti BCA pada PT. Bank Central Asia Tbk. Kantor Cabang Utama Jambi (BCA). BCA dipilih sebagai lokasi penelitian karena merupakan salah satu bank swasta terbesar nasional. Sesuai dengan slogan "Senantiasa di Sisi Anda", BCA terus berupaya memberikan layanan dan solusi terbaik bagi nasabah. Dengan memiliki 21.000 karyawan di seluruh cabang di Indonesia dan di luar negeri, BCA terus berusaha meningkatkan kualitas layanan kepada nasabah yang diberikan oleh seluruh karyawannya.

\section{Tinjauan Pustaka}

Manajemen Sumber Daya Manusia adalah ilmu dan seni mengatur hubungan dan peranan tenaga kerja agar efektif dan efisien membantu terwujudnya tujuan perusahaan, karyawan dan masyarakat. Manajemen Sumber Daya Manusia berhubungan dengan bagaimana sebuah organisasi merancang sistem formal yang 
menjamin pemanfaatan sumber daya manusia secara efektif dan efisien guna mendukung pencapaian tujuan dan rencana strategis organisasi. Manajemen Sumber Daya Manusia adalah kebijakan dan praktik menentukan aspek manusia atau sumber daya manusia dalam posisi manajemen, termasuk merekrut, menyaring, melatih, memberi penghargaan dan penilaian. Motivasi merupakan dorongan untuk bertindak terhadap serangkaian proses perilaku manusia dengan mempertimbangkan arah, intensitas dan ketekunan pada pencapaian tujuan. Motivasi adalah suatu faktor yang mendorong seseorang untuk melakukan suatu aktivitas tertentu oleh karena itu motivasi seringkali diartikan pula sebagai faktor pendorong perilaku seseorang. Motivasi merupakan kesediaan mengeluarkan tingkat upaya tinggi ke arah tujuan organisasi yang dikondisikan oleh kemampuan upaya untuk memenuhi kebutuhan individual. (Adisetiawan, 2016)

Pada tahun 1959, berdasarkan atas penelitian yang dilakukan Herzberg terhadap 250 responden pada sembilan buah perusahaan di Pittsburg, dilakukan pengujian hubungan kepuasan dengan produktivitas. Herzberg mengembangkan teori hierarki kebutuhan Maslow menjadi teori dua faktor tentang motivasi. Dua faktor yang dapat menyebabkan timbulnya rasa puas atau tidak puas menurut Herzberg, yaitu faktor pemeliharaan (hygiene factors) dan faktor pemotivasian (motivator factors) karena kondisi itu diperlukan untuk memelihara tingkat kepuasan yang layak. Faktor pemuas yang disebut juga motivator factor merupakan faktor pendorong seseorang untuk berprestasi yang bersumber dari dalam diri seseorang (kondisi intrinsik). Motivator factor tersebut terdiri dari 5 poin antara lain:

1. Prestasi yang diraih (Achievement).

Keberhasilan seorang pegawai dapat dilihat dari prestasi yang diraihnya. Agar seorang pegawai dapat berhasil dalam melakasanakan pekerjaannya, maka pemimpin harus mempelajari bawahannya dan pekerjaannya dengan memberikan kesempatan kepadanya agar bawahan dapat berusaha mencapai hasil yang terbaik. Bila bawahan telah berhasil mengerjakan pekerjaannya, pemimpin harus menyatakan keberhasilan itu.

2. Pengakuan orang lain (Recognition).

Sebagai lanjutan dari keberhasilan pelaksanaan, pimpinan harus memberi pernyataan pengakuan terhadap keberhasilan bawahan dapat dilakukan dengan berbagai cara yaitu:

a. Langsung menyatakan keberhasilan di tempat pekerjaannya, lebih baik dilakukan sewaktu ada orang lain.

b. Surat penghargaan.

c. Memberi hadiah berupa uang tunai.

d. Memberikan medali, surat penghargaan dan hadiah uang tunai.

e. Memberikan kenaikan gaji promosi.

3. Tanggung jawab (Responsibility).

Agar tanggung jawab benar menjadi faktor motivator bagi bawahan, pimpinan harus menghindari supervisi yang ketat, dengan membiarkan bawahan bekerja sendiri sepanjang pekerjaan itu memungkinkan dan menerapkan prinsip partisipasi. Diterapkannya prinsip partisispasi membuat bawahan sepenuhnya merencanakan dan melaksanakan pekerjaannya. Namun demikian atasan tetap harus menjaga keamanan, kualitas, kebenaran, dan pencapaian target atas tanggung jawab yang diberikan kepada bawahan.

4. Peluang untuk maju (Advancement).

Pengembangan merupakan salah satu faktor motivator bagi bawahan. Faktor pengembangan ini benarbenar berfungsi sebagai motivator, maka pemimpin dapat memulainya dengan melatih bawahannya untuk memberikan pekerjaan dengan tanggung jawab yang lebih. Bila ini sudah dilakukan selanjutnya pemimpin memberi rekomendasi tentang bawahan yang siap untuk pengembangan, untuk menaikkan pangkatnya, dikirim mengikuti pendidikan dan pelatihan lanjutan.

5. Kepuasan kerja itu sendiri (The work it self).

Pimpinan membuat usaha-usaha nyata dan meyakinkan, sehingga bawahan mengerti akan pentingnya pekerjaan yang dilakukannya dan berusaha menghindar dari kebosanan dalam pekerjaan bawahan serta mengusahakan agar setiap bawahan sudah tepat dalam pekerjaannya. 
Sedangkan faktor pemelihara (maintenancefactor) disebut juga hygienefactors merupakan faktor yang berkaitan dengan pemenuhan kebutuhan untuk keberadaan karyawan sebagai manusia, pemeliharaan ketentraman dan kesehatan. Faktor ini juga disebut dissatisfier (sumber ketidakpuasan) yang merupakan tempat pemenuhan kebutuhan tingkat rendah yang dikualifikasikan ke dalam faktor ekstrinsik, meliputi 6 poin antara lain:

1. Kompensasi (Payment \& status).

Pada umumnya masing-masing manajer tidak dapat menentukan sendiri skala gaji yang berlaku didalam unitnya. Namun demikian masing-masing manajer mempunyai kewajiban menilai apakah jabatan-jabatan dibawah pengawasannya mendapat kompensasi sesuai pekerjaan yang mereka lakukan. Para manajer harus berusaha untuk mengetahui bagaimana jabatan didalam kantor diklasifikasikan dan elemen-elemen apa saja yang menentukan pengklasifikasian itu.

2. Keamanan dan Keselamatan Kerja (Job security).

Keselamatan dan kesehatan kerja perlu terus dibina agar dapat meningkatkan kualitas keselamatan dan kesehatan kerja karyawan. Agar pembinaan dapat berjalan dengan baik, antara lain dapat dilakukan caracara berikut ini :

a. Tanamkan dalam diri karyawan keyakinan bahwa mereka adalah pihak yang paling menentukan dalam pencegahan kecelakaan.

b. Tunjukkan pada karyawan bagaimana mengembangkan perilaku kerja yang aman.

c. Berikan teknik pencegahan kecelakaan secara spesifik.

d. Buatlah contoh yang baik.

e. Tegakkan standar keselamatan kerja secara tegas.

3. Kondisi Kerja (Working condition).

Masing-masing manajer dapat berperan dalam berbagai hal agar keadaan masing-masing bawahannya menjadi lebih sesuai, misalnya ruangan khusus bagi unitnya, penerangan, perabotan suhu udara dan kondisi fisik lainnya. Menurut Herzberg seandainya kondisi lingkungan yang baik dapat tercipta, prestasi yang tinggi dapat tercipta, prestasi tinggi dapat dihasilkan melalui kosentrasi pada kebutuhan-kebutuhan ego dan perwujudan diri yang lebih tinggi.

4. Kebijakan (Company policy \& administration).

Yang menjadi sorotan disini adalah kebijaksaan personalia. Kantor personalia umumnya dibuat dalam bentuk tertulis. Biasanya yang dibuat dalam bentuk tertulis adalah baik, karena itu yang utama adalah bagaimana pelaksanaan dalam praktek. Pelaksanaan kebijaksanaan dilakukan masing-masing manajer yang bersangkutan. Dalam hal ini supaya mereka berbuat seadil-adilnya.

5. Supevisi Teknis (Supervision technical.

Dengan supervisi teknis yang menimbulkan kekecewaan yaitu adanya kurangnya kemampuan teknis dipihak atasan, bagaimana caranya mensupervisi dari segi teknis pekerjaan yang merupakan tanggung jawabnya, atau atasan mempunyai kecakapan teknis yang lebih rendah dari yang diperlukan dari kedudukannya. Untuk mengatasi hal ini para pimpinan harus berusaha memperbaiki dirinya dengan jalan mengikuti pelatihan dan pendidikan.

6. Hubungan Interpersonal antar teman sejawat, dengan atasan dan dengan bawahan (Interpersonal relation).

Interpersonal relation menunjukkan hubungan perseorangan antara bawahan dengan atasannya, dimana kemungkinan bawahan merasa tidak dapat bergaul dengan atasannya. Agar tidak menimbulkan kekecewaaan pegawai, maka minimal ada tiga kecakapan harus dimiliki setiap atasan yakni :

a. Technical Skill (Kecakapan teknis).

Kecakapan ini sangat diperlukan bagi pimpinan tingkat terbawah dan tingkat menengah, ini meliputi kecakapan menggunakan metode dan proses pada umumnya berhubungan dengan kemampuan menggunakan alat.

b. Human Skill (Kecakapan humanis).

Kemampuan untuk bekerja didalam atau dengan kelompok, sehingga dapat membangun kerjasama dan mengkoordinasikan berbagai kegiatan. 
c. Conseptual Skill (Kecakapan konseptual).

Kemampuan memahami kerumitan organisasi sehingga dalam berbagai tindakan yang diambil dalam tekanan selalu dalam usaha merealisasikan tujuan organisasi keseluruhan.

Selanjutnya pada komitmen organisasi, bisa tumbuh disebabkan karena individu memiliki ikatan emosional terhadap perusahaan yang meliputi dukungan moral dan menerima nilai yang ada di dalam perusahaan serta tekad dari dalam diri untuk mengabdi pada perusahaan. Komitmen organisasi adalah keinginan kuat untuk tetap bertahan sebagai anggota organisasi, keinginan untuk berusaha sesuai keinginan organisasi, keyakinan tertentu dan penerimaan nilai dan tujuan organisasi. Newstrommemberikan pengertian yang sama antara Organizational Commitment dengan Employee Loyalty, yaitu sebagai suatu tingkatan di mana pekerjamengidentifikasi dengan organisasi dan ingin melanjutkan secara aktif berpartisipasi di dalamnya. Komitmen organisasional menurut Colquitt, LePine, dan Wessonadalah sebagai keinginan pada sebagian pekerja untuk tetap menjadi anggota organisasi.Komitmen organisasional memengaruhi apakah seorang pekerja tetap tinggal sebagai anggota organisasi (is retained) atau meninggalkan untuk mengejar pekerjaan lain (turns over). Komitmen karyawan telah didefinisikan sebagai upaya karyawan untuk mencapai tujuan organisasi, dan ditemukanhubungan yang signifikan antara motivasi karyawan dan komitmen karyawan.. Agar karyawan puas dan berkomitmen terhadap pekerjaan mereka, ada kebutuhan untuk strategi motivasi yang kuat dan efektif di organisasi. Ditemukan bahwa motivasi kerja sangat positif terkait dengan organisasi. Komitmen organisasi dan motivasi kerja saling terkait. Terdapat beberapa faktor penentu komitmen seseorang terhadap organisasinya

1. Komitmen dipengaruhi oleh beberapa aspek dalam lingkup pekerjaan itu sendiri yang disebut faktor organisasi. Faktor ini akan membentuk sikap bertanggung jawab terhadap keberhasilan tugas yang diemban.

2. Komitmen organisasi dipengaruhi oleh alternatif kesempatan kerja yang dimiliki pekerja yang disebut faktor non-organisasi. Semakin besar peluang untuk berpindah kerja dan semakin besar hasratnya terhadap alternatif pekerjaan ditempat lain, komitmen pekerja pada organisasinya cenderung semakin rendah.

3. Komitmen pekerja pada organisasinya dipengaruhi oleh faktor karakteristik diri pekerja. Faktor ini membentuk komitmen inisial, yaitu komitmen awal yang timbul pada saat pekerja baru saja mulai masuk sebagai anggota organisasi. Seseorang yang mempunyai komitmen tinggi, pada saat mulai bekerja mempunyai kecenderungan untuk tidak berpindah pekerjaan untuk jangka waktu relatif lama. Termasuk faktor ini adalah kepuasan kerja, usia senioritas, dan lama bekerja. Semakin usia tua pekerja atau semakin lama bekerja dan semakin senior, serta semakin tinggi kepuasan terhadap karyawanya orang tersebut cenderung memiliki komitmen yang lebih tinggi.

\section{Hipotesis}

Atas dasar landasan toeri dan kerangka pemikiran di atas, maka penulis menggunakan hipotesis penelitian sebagai berikut:

1. Diduga motivasi kerja dan komitmen organisasi karyawan magang Bakti BCA pada PT. Bank Central Asia Tbk. Kantor Cabang Utama Jambi rendah.

2. Diduga motivasi kerja berpengaruh terhadap komitmen organisasi karyawan magang Bakti BCA pada PT. Bank Central Asia Tbk. Kantor Cabang Utama Jambi.

\section{METODE}

Dalam penelitian ini penulis menggunakan metode deskriptif verifikatifdengan tujuan menjelaskan, meringkaskan berbagai kondisi, berbagai situasi, atau berbagai variabel yang timbul dimasyarakat yang menjadi objek penelitian itu berdasarkan apa yang terjadi. Kemudian mengangkat ke permukaan karakter atau gembaran tentang kondisi, situasi ataupun variabel tersebut. Jenis data dalam penelitian ini ada dua macam, yaitu jenis data primer dan jenis data sekunder. 
1. Data primer yaitu data yang dibuat oleh peneliti untuk maksud khusus menyelesaikan permasalahan yang sedang ditanganinya. Data dikumpulkan sendiri oleh peneliti langsung dari sumber pertama atau tempat objek penelitian dilakukan.

2. Data sekunder yaitu data yang telah dikumpulkan untuk maksud selain menyelesaikan masalah yang sedang dihadapi. Data ini dapat ditemukan dengan cepat. Dalam penelitian ini yang menjadi sumber data sekunder adalah literatur, artikel, jurnal serta situs di internet yang berkenaan dengan penelitian yang dilakukan.

Metode pengumpulan data yang digunakan adalah:

1. Penelitian Kepustakaan (Library Research).

Dalam penelitian ini penulis mengumpulkan data dengan cara membaca, mempelajari dan menelaah literatur-literatur yang relevan dengan topik yang dibahas. Penelitian kepustakaan dimaksudkan untuk memperoleh data sekunder dalam menunjang data primer yang telah didapat dari penelitian lapangan.

2. Penelitian lapangan (fieldResearch).

Untuk mendapatkan data primer dilakukan dengan cara penyebaran kuesioner dan wawancara.

Teknik yang digunakan dalam pengambilan sampel adalah total sampling atau sampel jenuh dan sering disebut sebagai sensus, dimana seluruh populasi digunakan sebagai sampel. Sampel jenuh yaitu teknik penentuan sampel dengan cara menggambil seluruh anggota populasi sebagai responden atau sampel. Peneliti mengambil seluruh populasi karyawan magang Bakti yang ada di BCA Jambi pada tahun 2018 yang berjumlah 60 orang untuk dijadikan responden. Untuk menjawab tujuan pertama dan hipotesis pertama digunakan analisis deskriptif dengan alat analisis rentang skala Likert (Likert Scale). Analisis deskriptif mempunyai fungsi untuk memberikan gambaran umum tentang data yang telah diperoleh. Dasar penafsiran yang digunakan dalam penelitian ini mengacu dari skor penafsiran yaitu mulai darisangat rendah, rendah, sedang, tinggi dan sangat tinggi. Untuk menjawab tujuan penelitian kedua digunakan analisis regresi linier sederhana. Rumus persamaan regresi linier sederhana adalah sebagai berikut:

$\mathrm{Y}=\mathrm{a}+\mathrm{bX}+\mathrm{e}$

Keterangan : Y : Komitmen organisasi; a : Konstanta (harga Y untuk X =0; b : Angka arah (koefisien regresi), bila $\mathrm{b}$ positif (+) maka arah regresi naik, dan bila $\mathrm{b}$ negatif (-) maka arah regresi turun; $\mathrm{X}$ : Motivasi kerja; e : Error

\section{Pengujian Hipotesis Uji Parsial (Uji t)}

1. Rancangan Hipotesis

Ho: Motivasi kerja diduga tidak berpengaruh signifikanterhadap komitmen organisasi.

$\mathrm{H}_{1}$ : Motivasikerjadidugaberpengaruhsignifikanterhadapkomitmen organisasi.

2. Menghitung $t$ tabel menentukan harga $t$ tabel yaitu didapat dari membaca tabel distribusi $t$ untuk taraf signifikansi ( $\dot{\alpha}$ tertentu) dan $\mathrm{df}=\mathrm{n}-\mathrm{k}-1$. $^{[10]}$

Dalam hal ini $\mathrm{n}$ adalah jumlah sampel dan $\mathrm{k}$ adalah banyaknya variabel bebas sehingga df $=60-1-1=$ 58, dan t tabeı dengan tingkat kepercayaan $95 \%$ adalah 1,67155.

3. Kriteria keputusan.

Jika $t_{\text {hitung }}>\mathrm{t}_{\text {tabel }}$ maka Ho ditolak dan $\mathrm{H}_{1}$ diterima artinya terdapat pengaruh signifikan antara motivasi kerja terhadap komitmen organisasi.

Jika $t_{\text {hitung }} \leq t_{\text {tabel }}$ maka Ho diterima dan $\mathrm{H}_{1}$ ditolak artinya tidak terdapat pengaruh signifikan antara motivasi kerja terhadap komitmen organisasi.

\section{Operasional Variabel}

Operasional variabel berisi tabel-tabel tentang uraian setiap variabel penelitian menjadi dimensidimensi, dan dari dimensi-dimensi menjadi indikator-indikatornya. Setiap indikator ditetapkan satuan pengukuran serta skala pengukurannya. Motivasi merupakan kesediaan mengeluarkan tingkat upaya tinggi ke arah tujuan organisasi yang dikondisikan oleh kemampuan upaya untuk memenuhi kebutuhan individual. Herzberg mengembangkan teori hierarki kebutuhan Maslow menjadi teori dua faktor tentang motivasi. Dua faktor yang dapat menyebabkan timbulnya rasa puas atau tidak puas menurut Herzberg, yaitu faktor 
pemeliharaan (hygiene factors) dan faktor pemotivasian (motivator factors) karena kondisi itu diperlukan untuk memelihara tingkat kepuasan yang layak. Varibel motivasi kerja (X) meliputi faktor sebagai berikut: Prestasi yang diraih; Pengakuan orang lain; Tanggung jawab; Peluang untuk maju; Kepuasan kerja; Kompensasi; Keamanan dan keselamatan kerja; Kondisi kerja; Kebijakan; Supervisi teknis; dan Hubungan interpersonal. Komitmen organisasi adalah keinginan kuat untuk tetap bertahan sebagai anggota organisasi, keinginan untuk berusaha sesuai keinginan organisasi, keyakinan tertentu dan penerimaan nilai dan tujuan organisasi. Variabel komitmen oraganisasi meliputi faktor sebagai berikut: Faktor organisasi; Faktor nonorganisasi; dan Faktor karakteristik diri pekerja.

\section{Uji Validitas}

Validitas didefinisikan sebagai ukuran seberapa akurat suatu alat tes melakukan fungsi ukurannya. Instrumen dikatakan valid apabila mampu mengukur apa yang diinginkan dan dapat mengungkapkan data dari variabel yang diteliti secara tepat. Uji validitas dalam penelitian ini dengan menggunakan kriteria yang diambil dari alat ukur itu sendiri, yaitu dengan cara mengkorelasikan antara skor item dengan skor total (keseluruhan item), yang disebut validitas item yang digunakan dalam uji validitas tersebut adalah teknik koefisien korelasi Moment Pearson (Metode Least Square). Nilai koefisien korelasi $\mathrm{r}$ adalah -1 sampai +1 dengan kriteria pemanfaatan apabila $r=-1$ artinya negatif sempurna; $r=0$ artinya tidak ada korelasi; dan $r=$ 1 berarti korelasi sangat kuat. Sedangkan arti harga $r$ akan dikonsultasikan dengan tabel interprestasi sebagai berikut:

\begin{tabular}{cl}
\hline Interval Koefisien & Tingkat Keeratan Hubungan \\
\hline $0,80-1$ & Sangat Kuat \\
$0,60-0,799$ & Kuat \\
$0,40-0,599$ & Cukup \\
$0,20-0,399$ & Lemah \\
$0,00-0,199$ & Sangat lemah \\
\hline
\end{tabular}

\section{HASIL}

\section{Karakteristik Responden}

Metode pengumpulan data dilakukan dengan cara menyebarkan kuesioner secara langsung kepada 60 orang responden magang Bakti BCA. Responden ini merupakan populasi dari magang Bakti BCA pada BCA KCU Jambi. Karakteristik responden dibedakan dari kelompok usia, jenis kelamin, tingkat pendidikan, dan masa kerja. Karakteristik responden berdasarkan kelompok usia menyebar dari usia 18 tahun sampai dengan usia 29 tahun. Diketahui bahwa jumlah responden tertinggi adalah pada kelompok usia $21-23$ tahun dengan jumlah 24 orang atau $40 \%$ dari kesuluruhan total responden, sedangkan jumlah responden terendah adalah pada kelompok usia 27 - 29 tahun dengan jumlah 6 orang atau 10\% dari kesuluruhan total responden. Selebihnya responden dengan kelompok usia 18 - 20 tahun dan $24-26$ tahun berjumlah sama yaitu masingmasing 15 orang atau sebesar $25 \%$ dari keseluruhan total responden. Diketahui bahwa responden dengan jenis kelamin perempuan lebih banyak dari responden dengan jenis kelamin laki-laki, dengan komposisi masingmasing 45 orang $(75 \%)$ responden adalah berjenis kelamin perempuan dan 15 orang $(25 \%)$ responden berjenis kelamin laki-laki. Karakteristik responden berdasarkan tingkat pendidikan dibedakan menjadi tiga, yaitu responden dengan pendidikan terakhir SLTA, diploma, dan sarjana (S1/S2). Diketahui bahwa responden dengan tingkat pendidikan SLTA lebih dominan dibandingkan dengan responden dengan tingkat pendidikan diploma dan sarjana (S1/S2). Responden dengan tingkat pendidikan SLTA berjumlah 27 orang atau sebesar $45 \%$ dari total keseluruhan responden. Sedangkan responden dengan tingkat pendidikan diploma berjumlah 15 orang atau sebesar $25 \%$ dari total keseluruhan responden, dan rseponden dengan tingkat pendidikan sarjana (S1/S2) berjumlah 18 orang atau sebesar 30\% dari total keseluruhan responden. Karakteristik Responden Berdasarkan Masa Kerja dikelompokkan menjadi tiga tingkatan, yaitu kelompok responden dengan masa kerja 1 tahun, kelompok responden dengan masa kerja 2 tahun, dan kelompok responden dengan masa kerja 3 tahun. Yang termasuk dalam kelompok responden dengan masa kerja 1 tahun adalah responden yang bekerja pada 
masa kerja kontrak tahun pertama. Dan yang termasuk dalam kelompok responden dengan masa kerja 2 tahun adalah responden yang bekerja pada masa kerja kontrak tahun kedua. Sedangkan yang termasuk dalam kelompok responden dengan masa kerja 3 tahun adalah responden yang bekerja pada masa kerja kontrak tahun ketiga. Diketahui bahwa responden dengan masa kerja 2 tahun lebih dominan dibandingkan dengan responden dengan masa kerja 1 dan 3 tahun. Jumlah responden dengan masa kerja 1 tahun adalah sebanyak 15 orang atau sebesar 25\% dari total keseluruhan responden. Sedangkan responden dengan masa kerja 2 tahun berjumlah 33 orang atau sebesar 55\% dari total keseluruhan responden. Dan responden dengan masa kerja 3 tahun berjumlah 12 orang atau sebesar $20 \%$ dari total total keseluruhan responden.

\section{Analisis dan Pembahasan}

Hasil jawaban responden atas pertanyaan kuesioner motivasi kerja sebanyak 22 pertanyaan dan kuesioner komitmen organisasi sebanyak 8 pertanyaan, maka dapat dibuat suatu kesimpulan dan analisa faktor-faktor mana saja dari variabel motivasi kerja $(\mathrm{X})$ dan variabel komitmen organisasi (Y) yang menunjukkan nilai sangat rendah, rendah, sedang, tinggi, dan sangat tinggi.Berdasarkan rekap jawaban responden atas pertanyaan motivasi kerja tersebut, diketahui bahwa skor rata-rata motivasi kerja magang Bakti BCA pada BCA KCU Jambi adalah sebesar 150,73 dan dapat diartikan bahwa motivasi kerja magang Bakti BCA relatif masih rendah. 11 faktor motivasi kerja yang diteliti, responden magang Bakti BCA relatif puas pada faktor keamanan dan keselamatan kerja di BCA dengan skor 207 yang dapat diartikan relatif tinggi. Ketidakpuasan magang Bakti BCA bekerja di BCA KCU Jambi yang menyebabkan motivasi kerja sangat rendah disebabkan oleh faktor supervisi teknis tercermin dengan skor prestasi yang diraih sebesar 93. Selanjutnya faktor lain yang membuat motivasi kerja magang Bakti BCA bekerja di BCA rendah adalah faktor prestasi yang diraih dengan skor 114, pengakuan oranglain dengan skor 118, peluang untuk maju dengan skor 141, kepuasan kerja dengan skor 146, dan kebijakan dengan skor 129. Sedangkan faktor tanggung jawab dengan skor 163, kompensasi dengan skor 193, kondisi kerja dengan skor 194, dan hubungan interpersonal dengan skor 160 menggambarkan bahwa faktor tersebut relatif tidak terlalu mempengaruhi (sedang) terhadap motivasi kerja magang Bakti BCA. Berdasarkan rekap jawaban responden atas pertanyaan komitmen organisasi tersebut, diketahui bahwa skor rata-rata komitmen organisasi magang Bakti BCA pada BCA KCU Jambi adalah sebesar 133,33 dan dapat diartikan bahwa komitmen organisasi magang Bakti BCA relatif masih rendah. 3 faktor motivasi kerja yang diteliti pada responden magang Bakti BCA, yaitu faktor organisasi, faktor non organisasi, dan faktor karakteristik diri pekerja, semuanya menggambarkan tingkat komitmen organisasi yang rendah. Dengan faktor karakteristik diri pekerja memperoleh skor terendah yaitu sebesar 117. Faktor organisasi dan faktor non organisasi relatif sama pengaruhnya kepada komitmen organisasi magang Bakti BCA pada BCA KCU Jambi. Faktor organisasi memperoleh skor 143 dan faktor non organisasi memperoleh skor 140 .

Hasil perhitungan persamaan regresi linear sederhana, pengaruh motivasi kerja terhadap komitmen organisasi karyawan magang Bakti BCA pada BCA KCU Jambi dapat dinyatakan dalam persamaan matematika sebagai berikut: $\mathrm{Y}=0,301+0,773 \mathrm{X}$

Persamaan ini menyatakan bahwa koefisien regresi motivasi kerja mempunyai hubungan arah yang positif terhadap komitmen organisasi karyawan magang Bakti BCA pada BCA KCU Jambi. Artinya adalah jika motivasi kerja karyawan magang Bakti BCA naik maka komitmen organisasi karyawan magang Bakti BCA juga naik. Sebaliknya, jika motivasi kerja karyawan magang Bakti BCA turun maka komitmen organisasi karyawan magang Bakti BCA juga turun. Konstanta sebesar 0,301 artinya jika motivasi kerja sama dengan nol, maka komitmen organisasi magang Bakti BCA adalah sebesar 0,301. Koefisien variabel pengaruh motivasi kerja terhadap komitmen organisasi magang Bakti BCA sebesar 0,773 artinya jika terjadi perubahan pada motivasi kerja sebesar satu satuan maka komitmen organisasi magang Bakti BCA akan mengalami perubahan sebesar 0,773 satuan dengan arah yang sama. Motivasi kerja berpengaruh signifikan terhadap komitmen organisasi karyawan magang Bakti BCA pada BCA KCU Jambi. Hal ini dapat dibuktikan melalui

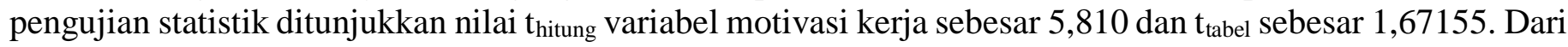
hasil perbandingan maka dapat diketahui $\mathrm{t}_{\text {hitung }} 5,810$ lebih besar dari $\mathrm{t}_{\text {tabel }}$ 1,67155 pada tingkat keyakinan $95 \%$, dengan kriteria keputusan $t_{\text {hitung }}>t_{t a b e l}$ maka hipotesis $\mathrm{H}_{0}$ ditolak dan hipotesis $\mathrm{H}_{1}$ diterima artinya 
motivasi kerjaberpengaruh signifikan terhadap komitmen organisasi karyawan magang Bakti BCA pada BCA KCU Jambi. Besar hubungan antara variabel motivasi kerja dengan komitmen organisasi yang dihitung dengan koefisien korelasi adalah 0,607. Hal ini menunjukan hubungan positif yang kuat antara variabel motivasi kerja dengan variabel komitmen organisasi karyawan magang Bakti BCA pada BCA KCU Jambi. Sementara nilai $\mathrm{R}$ square adalah 0,368 (pengkuadratan dari koefisien korelasi, atau $0,607^{2}=0,368$ ). Koefisien determinasi ( $R$ square), dalam hal ini menjelaskan bahwa pengaruh variabel motivasi kerja dapat menjelaskan variabel komitmen organisasi karyawan magang Bakti BCA pada BCA KCU Jambi sebesar 36,8 \%. Sedangkan sisanya $63,2 \%(100 \%-36,8 \%=63,2 \%)$ dipengaruhi atau dijelaskan oleh faktor-faktor lain yang tidak diamati dalam penelitian ini. Jika nilai $\mathrm{R}$ square yang kecil berarti kemampuan variabel-variabel independen sangat rendah dalam menjelaskan variabel dependen. Sebaliknya, nilai R square yang mendekati satu menandakan variabel independen memberikan hampir semua informasi yang dibutuhkan oleh variabel dependen.

\section{SIMPULAN}

Berdasarkan uraian-uraian dari hasil penelitian dan pembahasan maka dapat diambil kesimpulan sebagai berikut:

1. Persamaan regresi linier sederhana $\mathrm{Y}=0,301+0,773 \mathrm{X}$, dengan konstanta sebesar 0,301 memberikan arti bahwa komitmen organisasi karyawan magang Bakti BCA pada BCA KCU Jambi bernilai sebesar 0,301 apabila variabel motivasi kerja tidak ada atau sama dengan nol. Koefisien regresi motivasi kerja sebesar 0,773, menunjukkan jika motivasi kerja mengalami kenaikan satu satuan, maka komitmen organisasi karyawan magang Bakti BCA pada BCA KCU Jambi akan mengalami peningkatan sebesar 0,773 .

2. Berdasarkan uji $t$ dapat diketahui $t_{\text {hitung }}$ lebih besar dari $t_{\text {tabel}}$, $\left(t_{\text {hitung }} 5,810>1,67155 t_{\text {tabel }}\right.$ ) maka hipotesis $\mathrm{H}_{0}$ ditolak dan hipotesi $\mathrm{H}_{1}$ diterima artinya motivasi kerja berpengaruh signifikan terhadap komitmen organisasi karyawan magang Bakti BCA pada BCA KCU Jambi.

3. Besarnya pengaruh variabel motivasi kerja menjelaskan variabel komitmen organisasi karyawan magang Bakti BCA pada BCA KCU Jambi sebesar 36,8\%, sedangkan sisanya 63,2\% dipengaruhi atau dijelaskan oleh faktor-faktor lain yang tidak diteliti dalam penelitian ini. Besar hubungan antara variabel motivasi kerja dengan komitmen organisasi yang dihitung dengan koefisien korelasi adalah 0,607 menunjukan hubungan yang kuat dan bersifat positif.

4. Motivasi kerja dan komitmen organisasi karyawan Magang Bakti BCA pada BCA KCU Jambi relatif rendah.

\section{DAFTAR PUSTAKA}

Adisetiawan, R., 2014, Performance Mahasiswa Fakultas Ekonomi Universitas Batanghari Jambi, Jurnal Ilmiah Universitas Batanghari Jambi, 14(3), 1-10

Adisetiawan, R., 2016, Faktor yang Mempengaruhi Lilusan SMA dalam Memilih Fakultas Ekonomi Program Studi Manajemen Universitas Batanghari, Jurnal Ilmiah Universitas Batanghari Jambi, 16(3), 1-11

George L., Sabapathy T. 2011. Work Motivation of Teachers: Relationship with Organizational Commitment. Canadian Social Science, 7, 1, 90-99

Hanggraeni, Dewi. 2012. Manajemen Sumber Daya Manusia. Jakarta: Lembaga Penerbit Fakultas Ekonomi Universitas Indonesia

Hasibuan, Malayu SP (2011), Manajemen Sumber Daya, Jakarta: PT.Bumi Aksara

Husein, Umar. 2013. Riset Sumber Daya Manusia. Jakarta: Gramedia Pustaka Utama

Luthans.2011. Performance and Motivation. New York: Prentice Hall

Meyer, J.P, Allen N.J., and Smith C.A. 1993. Commitment Organizational and Occupations: Extension and Tes of Three Component Conceptualization. Journal of Applied Psychology. 78:538-551

Mohsan, F., Nawaz, M. M., Khan, M., Shaukat, Z., \& Aslam, N. 2004. Are Employee Motivation, Commitment and Job Involvement Inter-related: Evidence from Banking Sector of Pakistan. International Journal of Business and Social Science, 2, 17, 226-233 
Sedarmayanti. 2015. Sumber Daya Manusia dan Produktivitas Kerja. Bandung: CV Mandar Maju Sugiyono. 2013. Metode Penelitian Manajemen. Bandung: Alfabeta

Supardi. 2013. Aplikasi Statistika Dalam Penelitian. Jakarta: Change Publication

Sutrisno, Edy. 2011.Manajemen Sumber Daya Manusia.Jakarta: Kencana Prenada Media Group

Syekh, Sayid. 2011. Pengantar Statistik Ekonomi dan Sosial. Jakarta: Gaung Persada Pers

Warsi, S., Fatima, N., \& Sahibzada, S. A. 2009. Study on relationship between organizational commitment and its determinants among private sector employees of Pakistan, International Review of Business Research Papers, 5, 3, 399-410

Wibowo. 2013. Perilaku Dalam Organisasi. Jakarta: PT. Rajagrafindo

Zahari, M. 2015. Pengaruh Motivasi Terhadap Disiplin Kerja Pegawai pada Dinas Perindustrian dan Perdagangan Provinsi Jambi. Jurnal Ilmiah EKSIS, Vol.6 No.1, Mei 2015. 